\title{
BUD DORMANCY INTENSITY IN PEACH TREE CULTIVARS BY BIOLOGICAL AND TETRAZOLIUM TEST ${ }^{1}$
}

GISELDA ALVES ${ }^{2}$, LUIS ANTONIO BIASI ${ }^{3}$, LOUISE LARISSA MAY DE MIO ${ }^{3}$

\begin{abstract}
Temperate climate fruit trees often exhibit uneven budding and flowering, due to the low number of chilling hours that determine the occurrence of dormancy and its depth. The objective of this study was to determine the depth of bud dormancy in peach tree cultivars and evaluate the efficiency of the tetrazolium test for dormancy and comparing with biological test. Branches of the cultivars Aurora 1, Chimarrita, Chiripá, Coral, Eldorado, Granada, Leonense, Maciel, Marli, Premier, and Vanguard were collected between May and August 2008 at two locations: Curitiba and Lapa. The evaluation of dormancy was performed using a biological test of single node cuttings through the parameters: average time for bud burst, velocity of bud burst, final rate of bud burst and rate of vigorous bud burst. For the tetrazolium test, $300 \mathrm{mg}$ of buds was used and the color intensity readings were obtained using a spectrophotometer. The peach tree cultivars evaluated differ in the intensity of dormancy in late fall. The most intense endodormancy cultivars found were: Chiripá, Leonense and Eldorado cultivars, and the weaker cultivars found were: Aurora 1 and Maciel. The tetrazolium test was efficient at estimating the intensity of dormancy in peach trees when the occurrence of cold was suitable for installation endodormancy. At a location with the lowest occurrence of cold (Curitiba), the tetrazolium test did not simulated successfully the biological test results.
\end{abstract}

Index terms: Prunus persica, endodormancy, bud burst, botany, phisiology.

\section{INTENSIDADE DE DORMENCIA DE GEMAS EM CULTIVARES DE PESSEGUEIRO PELO TESTE BIOLOGICO E TETRAZÓLICO}

\begin{abstract}
RESUMO -Frutíferas de clima temperado, frequentemente apresentam deficiência e desuniformidade na brotação e floração, devido ao baixo número de horas de frio para a ocorrência da dormência e de sua profundidade. O objetivo deste trabalho foi determinar a intensidade da dormência de gemas de cultivares de pessegueiro e avaliar a eficiência do teste do tetrazólio para avaliar a dormência comparando com o teste biológico. Os ramos das cultivares Aurora 1, Chimarrita, Chiripá, Coral, Eldorado, Granada, Leonense, Maciel, Marli, Premier e Vanguarda, foram coletados entre maio e agosto de 2008 em dois locais: Curitiba e Lapa. A avaliação da dormência foi realizada pelo teste biológico de estacas de nós isolados por meio dos parâmetros: tempo médio para brotação, velocidade de brotação, taxa final de brotação e taxa de brotações vigorosas. Para o teste do tetrazólio utilizou-se $300 \mathrm{mg}$ de gemas e as leituras de intensidade de cor foram obtidas em espectrofotômetro. As cultivares de pessegueiro avaliadas diferem quanto a intensidade de dormência no final do outono, sendo a endodormência mais intensa nas cultivares Chiripá, Leonense e Eldorado e mais fraca nas cultivares Aurora 1 e Maciel. O teste do tetrazólio foi eficiente para estimar a intensidade de dormência das gemas de pessegueiro onde a ocorrência de frio foi adequada para a instalação da endodormência. No local com menor ocorrência de frio (Curitiba), o teste do tetrazólio não simulou com sucesso os resultados do teste biológico.
\end{abstract}

Termos para Indexação: Prunus persica, endodormência, brotação, botânica, fisiologia.

\footnotetext{
'(Trabalho 064-15). Recebido em: 09-03-2015. Aceito para publicação em: 22-07-2015.

${ }^{2}$ Eng. Agr., Dr, Universidade Federal do Paraná, Curitiba-PR. E-mail: giseldaalves@uol.com.br

${ }^{3}$ Eng. Agr., Dr., Prof. do Depto. de Fitotecnia e Fitossanitarismo. UFPR. Curitiba, Paraná. Bolsista de Produtividade em Pesquisa do CNPq.E-mails: maydemio@ufpr.br; biasi@ufpr.br
} 


\section{INTRODUCTION}

Dormancy is an important physiological condition in the adaptation of temperate climate fruit trees to environmental conditions. This phenomenon is characterized by the acquisition of cold resistance and growth control (LANG et al., 1987), in which the metabolic activities of the plant continue, although at reduced rates (PETRI et al., 2006). The dormancy may extend throughout the year via three processes: paradormancy, endodormancy and ecodormancy (LANG et al., 1987).

In the process of paradormancy, also known as correlative inhibition, the inactivation of the vegetative or floral meristem results from the influence of other plant organs on the bud. Endodormancy involves the paralysis of bud development to survive under critical environmental conditions of plant growth, such as low temperature and water deficit; plants only exit this phase when the intrinsic cold requirements of the bud have been met. In a production system, endodormancy is the most important stage for producers, because the poor or uneven budding may compromise both the production and the distribution of branches on the plant (CARVALHO; ALVES, 2007). Ecodormancy occurs after the overcoming of endodormancy and is characterized by the prevention of bud sprouts due to environmental conditions that limit plant growth, such as the lack of water or temperature extremes (LANG et al., 1987). After the suspension of the limiting factors on the plant, bud sprouting occurs.

Temperature is the main climate factor element related to the induction of dormancy in temperate fruit trees (EREZ, 2000). Low temperatures act in dormancy in two ways: temperature initially contributes to growth paralysis, cold acclimation and dormancy induction and subsequently acts in overcoming this state (HAWERROTH et al., 2010).

Due to the expansion of temperate fruit production in tropical and subtropical areas, physiological disorders related to deficient budding and blossoming occur more frequently and have a negative impact on productivity and fruit quality. Therefore, measurement of the dormancy intensity is essential to estimate a cultivar adaptation to the planting site.

The biological test applied in major temperate climate fruit crops is one of the most commonly used tests to estimate the degree of bud dormancy. This test consists of evaluating the growth capacity of the buds, isolated from the correlative influences of the plant as a whole, under controlled conditions (DENNIS, 2003). Another option to evaluate dormancy in buds is the tetrazolium test (CARVALHO et al., 2010b), an interesting alternative for quickly determining the intensity of dormancy that produces results in a few hours.

The objective of this study was to compare the depth of bud dormancy in peach tree cultivars grown in the Metropolitan Region of Curitiba and evaluate the efficiency of the Tetrazolium test compared to biological test to study dormancy.

\section{MATERIAL AND METHODS}

The study was conducted between May and August 2008. First, peach tree branches were gathered in two locations in the State of Paraná: a) Lapa (Espigão farm 2555'10” S, 49 57'26" W and altitude of $863 \mathrm{~m}$; b) Curitiba (experimental orchard of the Division of Agricultural Sciences of Federal University of Paraná located at $25^{\circ} 24^{\prime} 42^{\prime \prime}$ S, $49^{\circ} 14^{\prime}$ 53 " W and altitude of $945 \mathrm{~m}$ ). The climate at both orchards, according to the Köppen classification, is subtropical, with cool summers and no dry season $(\mathrm{Cfb})$

In both orchards productive branches of one year, situated in the middle position of the plant, were collected for the cultivars of Aurora 1, Chimarrita, Chiripá, Coral, Eldorado, Granada, Leonense, Maciel, Marli, Premier and Vanguarda. The plants were four years old and grafted onto the Capdeboscq rootstock; the training system used was Y.

The branch collection from each cultivar was held on 04/06/2008 in Curitiba and 06/06/2008 in Lapa, and the branches were transported to the Laboratory of Plant of UFPR for the dormancy evaluation using the biological and tetrazolium tests. The number of chill hours $\left(\leq 7.2{ }^{\circ} \mathrm{C}\right)$ was calculated from the temperature data provided by the Technological Institute SIMEPAR.

The biological test was performed with cuttings of $6 \mathrm{~cm}$ length each which were removed from the middle portion of the branch containing a trio of buds formed by a central vegetative bud and two lateral flower buds, located at the upper end. The experimental unit consisted of 10 cuttings placed in plastic pots containing moistened vermiculite substrate and covered with transparent plastic film, with four replications for a total of 40 cuttings per cultivar. The cuttings were placed in a room under controlled conditions of $25^{\circ} \mathrm{C}$ and a photoperiod of $16 \mathrm{~h}$.

The cuttings were evaluated individually, every two days, up to a maximum period of 35 days, until the observation of the bud burst green tip (GT) stage (when changes occur in the bud color, with a 
greenish shade at the apex) and the open leaves (OL) stage (when the emergence of open leaves occurs) (OLIVEIRA FILHO; CARVALHO, 2003). Based on these stages, the following were calculated: a) average time for bud burst (ABT), which represents the average number of days elapsed between the onset of the experiment and the detection of the GT stage; b) FRB - final rate of bud burst, which represents the percentage of cuttings with buds that reached the GT stage; c) RVB - rate of vigorous bud burst, which represents the percentage of cuttings with buds that evolved from GT stage to OL stage, given by the equation $\mathrm{RVB}=(\%$ cuttings with buds in OL stage) $\times 100 /$ FRB; d) VB - velocity of bud burst, which evaluates the occurrence of bud burst versus time of budding and is given by the equation $\mathrm{VB}=\Sigma$ (ni/ ti) (buds / day), where: ni $=$ number of buds that reached GT stage in time " $\mathrm{i}$ ", and ti $=$ time of testing after installation $(\mathrm{i}=1$ to 35$)$. From the results obtained using the biological test, the dormancy intensity (DI) of the cultivars were also calculated according to equation: $\mathrm{DI}=\mathrm{ATB} .(k \cdot \mathrm{FRB}$ $+w \cdot \mathrm{VB}+\mathrm{RVB})^{-1}$. The values of the constants $k$ and $w$ are resulting from the application of the correlation coefficients between FRB, VB and ATB (CARVALHO; BIASI, 2012).

The tetrazolium test was conducted only with the buds, which were removed from the branch through a longitudinal cut between the bud and the branch and another transverse cut at its point of insertion on the branch. For each cultivar, four analyses were performed, in June 2008.

Each analysis was conducted with a sample of $300 \mathrm{mg}$ of buds with lengthwise cuts to expose the interior tissue of the buds, and the test was then performed to avoid the oxidation of the tissues. The buds were maintained in open flasks containing 5 $\mathrm{ml}$ of the chloride salt 2,3,5-triphenyl tetrazolium (concentration 10 g. $\mathrm{L}^{-1}$ ) at $25^{\circ} \mathrm{C}$ for two hours to dye the living tissues. The solution color intensity readings were obtained using a spectrophotometer with $560 \mathrm{~nm}$ of absorbance (CARVALHO et al., 2010b).

The experimental design was based on random assignment, with eleven treatments and four replications for the two tests. Data normality was verified using the Shapiro-Wilk test, and the homogeneity was verified by Bartlett's test. The mathematical assumptions of the tests being met, the analysis of variance and group mean tests were performed using the Scott-Knott test at 5\% significance with the use of the computing application $\mathrm{R}$ ( $\mathrm{R}$ development core team, 2011).

\section{RESULTS AND DISCUSSION}

Significant differences were found between peach cultivars for most of the variables analyzed by the biological test and by the tetrazolium test, except for RVB, which exhibited no difference among the cultivars evaluated at the two locations (Table 1). There was no bud burst of Eldorado cultivar in the experiment located in Curitiba. The RVB observed may be considered high, as the average for all cultivars was $78.8 \%$ and $80.3 \%$, in Curitiba and Lapa respectively. According to Carvalho and Zanette (2004) a better way to assess the capacity of bud development is to use the variable rate of vigorous bud burst (RVB), which measures the percentage of cuttings with buds that evolved from Green Tip stage to Open Leaves stage. The collection made for this study at the beginning of June revealed that no cultivar was categorized by a dormancy level of "Absent" according to the DI scale (CARVALHO; BIASI, 2012). In Curitiba, the following were recorded: Aurora 1 (1.53) and Maciel (1.56) cultivars with "Weak" dormancy; Coral (2.19), Granada (2.21), Premier (2.99) and Vanguarda (3.40) with "Moderate" dormancy; Marli (3.82), Chimarrita (4.02) and Chiripá (7.59) with "Intense" dormancy and Leonense (11.37) with "Deep" dormancy. In Lapa, the following were found: Aurora 1 (1.86), Maciel (2.53) and Vanguarda (3.42) cultivars with "Moderate" dormancy; Marli (3.55), Coral (3.67), Granada (5.48), Premier (4.33) and Chimarrita (4.78) with "Intense" dormancy; Leonense (8.34), Eldorado (8.93), Chiripá (11.02) with "Deep" dormancy. The greatest intensity of dormancy from the Lapa orchard may be due to the larger number of chill hours before the branch samples were tested: 138 chill hours in Lapa versus, only 1 chill hour in Curitiba. However, despite the large difference in chill hours among the collection sites, the cultivars exhibited similar behavior regarding the variables analyzed using the biological test. The behavior of Chimarrita, which is the most widely grown cultivar in the region, was found to be very similar for DI: 4.02 in Curitiba and 4.78 in Lapa. The ATBs were also similar: 16.56 days for Curitiba and 18.01 days for Lapa (Table 1). Considering that ATB below 14 days may be indicative of the absence of endodormancy, especially if associated with FRB above 90\% (CARVALHO et al., 2010a), this suggests an independence inducing endodormancy on the occurrence of temperatures below $7.2^{\circ} \mathrm{C}$. Oliveira Filho and Carvalho (2003) found in peach tree buds of Eldorado and Agate cultivars and that the most intense endodormancy occurred with only 15 hours 
of cold $\left(<7.2^{\circ} \mathrm{C}\right)$.

The biological test demonstrated that cultivars differ in the average time to bud burst (ATB). The Chiripá cultivar, considered late maturing in the region (ALVES et al., 2012), had longer ATBs in both locations, which corresponds to greater depth of dormancy. However, in Curitiba, this cultivar did not differ from the Leonense, Marli and Chimarrita cultivars (intermediate maturing cultivars) and the Vanguard cultivar (early maturing cultivar), probably due to the low occurrence of cold; only 1 hour below $7.2^{\circ} \mathrm{C}$ was recorded at this location occurred prior to collecting the branches. The requirement for cold below $7.2^{\circ} \mathrm{C}$ of the cultivars evaluated in this study ranges from 150 (Aurora 1) to 500 chill hours (Chiripá) (CARAMORI et al., 2008). The higher ATB associated with low values of FRB and VB indicate the most intense endodormancy, as evidenced by the low ability of the bud to develop. The Aurora 1 and Maciel cultivars in both locations and Granada in Curitiba exhibited the shortest ATBs, demonstrating the greater aptitude of the bud to grow. The other cultivars exhibited variations in the sequence between the two studied areas, regardless of the maturation cycle. Environmental conditions may have an independent effect on the factors related with the endodormancy such as energetic metabolism of the bud, allocation of reserves, carbohydrate flux, short distance nutrient transfer, and hormonal regulation, making the evaluation of the dormancy intensity more difficult (CARVALHO et al., 2014).

Considering the two locations, the velocity of bud burst (VB) for the Leonense and Chiripá cultivars exhibited the lowest values, and the Maciel and Aurora 1 cultivars exhibited the highest values. However, the Leonense and Chiripá cultivars did not differ from the Marli, Chimarrita and Vanguard cultivars in Curitiba and the Eldorado cultivar in Lapa, and the Aurora 1 cultivar significantly differed from the others in Lapa and in Curitiba, being in the same group as the Maciel, Granada, Coral and Premier cultivars. These fluctuations in the VB values can be derived from the direct influence of the amount of cold in the ability to bud sprouting because, in the absence of cold, the buds exhibit slowing of the bud burst (VB) and reduction of the final rate of bud burst (FRB). The final rate of bud burst (FRB) of the Leonense cultivar was the lowest and significantly different from those of the other cultivars in Curitiba; the cultivar in Lapa was similar to the cultivars in Chiripá and Eldorado. This limitation on the bud growth (smaller FRB) and consequently on the bud burst speed may be imposed by endodormancy. According to Marquat et al. (1999), during the endodormancy period, the vegetative buds of peach trees are not characterized as major metabolic drains that diminish the mobilizing capacity of reserves for bud sprouting induction.

Absorbance readings also exhibited differences between cultivars, whereas in Curitiba, the highest absorbance was found for Premier cultivar, which was significantly different from all others, followed by Maciel and Vanguard. In Lapa, the highest absorbance was found in Aurora 1, followed by Vanguard and Premier. This result indicates that these cultivars had higher respiration in their buds, being closer to bud burst than the others. Relating this result with the other variables analyzed, significant correlations between the absorbance and the values of ATB, VB, FRB and DI in Lapa (Table 2 ) were found. The correlation was negative and high between the absorbance and the ATB (-0.8018), suggesting that the buds with lower ATB exhibited higher respiratory activity. Regarding VB and FRB the correlation was positive. This result reflected a high negative correlation between the absorbance and the DI (-0.8875), indicating that cultivars with greater intensity of dormancy have lower respiratory activity, which indicates that the tetrazolium test is viable for evaluation of the dormancy intensity of peach buds. However, in the evaluation of the same cultivars in Curitiba, no significant correlations were found between the absorbance and the other variables. This result may be due to the lack of cold weather that occurred in this location, only one chill hour below $7.2^{\circ} \mathrm{C}$, which can cause an imbalance in the input stages and in overcoming the endodormancy period. 
TABLE 1 - Average time for bud burst (ATB), final rate of bud burst (FRB), velocity of bud burst (VB), rate of vigorous bud burst (RVB), absorbance (ABS) and dormancy intensity (DI) of eleven peach cultivars collected in Curitiba and Lapa, Paraná.

\begin{tabular}{|c|c|c|c|c|c|c|c|}
\hline Cultivars & $\begin{array}{l}\text { ATB }^{1} \\
\text { (days) }\end{array}$ & $\begin{array}{c}\text { VB } \\
\text { (buds.days }^{-1} \text { ) }\end{array}$ & & $\begin{array}{l}\mathrm{B}^{-1} \\
0)\end{array}$ & $\begin{array}{l}\mathrm{RVB}^{1} \\
(\%)\end{array}$ & $\mathrm{ABS}^{2}$ & DI \\
\hline \multicolumn{8}{|c|}{ Curitiba } \\
\hline Chiripá & $23.23 \mathrm{a}$ & $0.21 b$ & 47.5 & $\mathrm{~b}$ & $80.00 \mathrm{~ns}$ & $72.76 \mathrm{c}$ & 7.59 \\
\hline Leonense & $19.11 \mathrm{a}$ & $0.13 b$ & 225 & $\mathrm{c}$ & 50.00 & $76.94 \mathrm{c}$ & 11.37 \\
\hline Marli & $18.35 \mathrm{a}$ & $0.42 \mathrm{~b}$ & 75.0 & $\mathrm{a}$ & 86.67 & $78.06 \mathrm{c}$ & 3.82 \\
\hline Chimarrita & $16.56 \mathrm{a}$ & $0.36 \mathrm{~b}$ & 50.0 & $\mathrm{~b}$ & 75.71 & $78.79 \mathrm{c}$ & 4.02 \\
\hline Vanguarda & $16.48 \mathrm{a}$ & $0.47 b$ & 72.5 & $\mathrm{a}$ & 77.83 & $117.19 b$ & 3.40 \\
\hline Coral & $14.83 \mathrm{~b}$ & $0.75 a$ & 92.5 & $\mathrm{a}$ & 97.50 & $92.59 \mathrm{c}$ & 2.19 \\
\hline Premier & $14.32 \mathrm{~b}$ & $0.54 \mathrm{a}$ & 62.5 & $\mathrm{a}$ & 75.71 & $129.37 \mathrm{a}$ & 2.99 \\
\hline Aurora 1 & $12.35 \mathrm{~b}$ & $1.20 \mathrm{a}$ & 82.5 & $\mathrm{a}$ & 81.67 & $84.08 \mathrm{c}$ & 1.53 \\
\hline Granada & $11.77 \mathrm{~b}$ & $0.67 \mathrm{a}$ & 67.5 & $\mathrm{a}$ & 69.79 & $88.68 \mathrm{c}$ & 2.21 \\
\hline Maciel & $9.60 \mathrm{~b}$ & $0.83 a$ & 67.5 & $\mathrm{a}$ & 93.30 & $117.89 b$ & 1.56 \\
\hline Eldorado & - & - & - & & - & - & - \\
\hline $\operatorname{cv}(\%)$ & 12.91 & 20.96 & 14.91 & & 21.59 & 7.96 & - \\
\hline \multicolumn{8}{|c|}{ Lapa } \\
\hline Chiripá & $22.98 \mathrm{a}$ & $0.12 d$ & 27.5 & $\mathrm{c}$ & $77.08 \mathrm{~ns}$ & $67.12 \mathrm{~h}$ & 11.02 \\
\hline Eldorado & $20.23 \mathrm{~b}$ & $0.15 d$ & 30.0 & $\mathrm{c}$ & 77.08 & $90.78 \mathrm{~g}$ & 8.93 \\
\hline Coral & $19.23 \mathrm{~b}$ & $0.46 \mathrm{~b}$ & 85.0 & $\mathrm{a}$ & 85.42 & $113.42 \mathrm{f}$ & 3.67 \\
\hline Marli & $19.17 \mathrm{~b}$ & $0.49 b$ & 90.0 & a & 72.43 & $102.07 \mathrm{~g}$ & 3.55 \\
\hline Granada & $18.92 \mathrm{~b}$ & $0.31 \mathrm{c}$ & 55.0 & b & 58.04 & $118.05 \mathrm{~d}$ & 5.48 \\
\hline Leonense & $18.79 \mathrm{~b}$ & $0.15 \mathrm{~d}$ & 27.5 & $\mathrm{c}$ & 83.33 & $94.65 \mathrm{~g}$ & 8.34 \\
\hline Chimarrita & $18.01 \mathrm{~b}$ & $0.31 \mathrm{c}$ & 52.5 & $\mathrm{~b}$ & 96.43 & $116.89 \mathrm{e}$ & 4.78 \\
\hline Vanguarda & $16.53 \mathrm{c}$ & $0.48 b$ & 72.5 & $\mathrm{a}$ & 75.15 & $125.54 b$ & 3.42 \\
\hline Premier & $16.06 \mathrm{c}$ & $0.34 \mathrm{c}$ & 47.5 & $\mathrm{~b}$ & 91.67 & $119.08 \mathrm{c}$ & 4.33 \\
\hline Maciel & $13.13 \mathrm{~d}$ & $0.58 b$ & 70.0 & $\mathrm{a}$ & 75.15 & $113.41 \mathrm{f}$ & 2.53 \\
\hline Aurora 1 & $13.06 \mathrm{~d}$ & $0.85 \mathrm{a}$ & 90.0 & $\mathrm{a}$ & 91.67 & $135.10 \mathrm{a}$ & 1.86 \\
\hline $\operatorname{cv}(\%)$ & 5.33 & 17.37 & 14.72 & & 13.6 & 6.25 & - \\
\hline
\end{tabular}

${ }^{1}$ Averages of the biological test node cuttings isolated; ${ }^{2}$ Averages verified by the tetrazolium test. Means followed by different letters in the columns differ by the Scott Knott test at a significance level of $5 \%$.

TABLE 2 - Correlation coefficients between the variables of the biological test and the tetrazolium test of peach buds collected in Curitiba and Lapa, Paraná.

\begin{tabular}{lcc}
\hline Correlation & Curitiba & Lapa \\
\hline ABS x ATB & $-0.5411 \mathrm{~ns}$ & $-0.8018^{* *}$ \\
ABS x VB & $0.2842 \mathrm{~ns}$ & $0.7577 * *$ \\
ABS x FRB & $0.2972 \mathrm{~ns}$ & $0.6686 *$ \\
ABS x RVB & $0.2471 \mathrm{~ns}$ & $0.2217 \mathrm{~ns}$ \\
ABS x DI & $-0.756 \mathrm{~ns}$ & $-0.8875 * *$ \\
ATB x VB & $-0.7967 * *$ & $-0.8032 * *$ \\
ATB x FRB & $-0.5064 \mathrm{~ns}$ & $-0.5360 \mathrm{~ns}$ \\
ATB x RVB & $-0.3095 \mathrm{~ns}$ & $-0.2777 \mathrm{~ns}$ \\
TMB x DI & $0.7559 *$ & $0.8112 * *$ \\
\hline
\end{tabular}

ABS-peach buds were submitted to the tetrazolium test and the color intensity reading was obtained on a spectrophotometer with 560 $\mathrm{nm}$ of absorbance; TMB - mean time of bud burst; FRB - final rate of bud burst; RVB - rate of vigorous bud burst; VB - velocity of bud burst. $* \mathrm{p}<0.05, * * \mathrm{p}<0.01$; ns: non-significant 


\section{CONCLUSION}

The evaluated peach cultivars were found to differ in the depth of dormancy in late fall; the most intense endodormancy was found on the cultivars Chiripá, Leonense and Eldorado, while weaker endodormancy was found in the Aurora 1 and Maciel cultivars.

The tetrazolium test was efficient for estimating the intensity of dormancy of peach buds in Lapa/PR where the occurrence of cold was sufficient for the onset of the endodormancy. In Curitiba/PR with a low occurrence of cold, tetrazolium test did not provide similar results to those of the biological test.

\section{REFERENCES}

ALVES, G.; SILVA, J.; MAY DE MIO, L.L.; BIASI, L.A. Comportamento fenológico e produtivo de cultivares de pessegueiro no município da Lapa, Paraná. Pesquisa Agropecuária Brasileira, Brasília, v.47, n.11, p.1596-1600, 2012.

CARAMORI, P.H.; CAVIGLIONE, J.H.; WREGE, M.S.; HERTER, F.G.; HAUAGGE, R.; GONÇALVES, S.L.; CITADIN, I.; RICCE, W.S. Zoneamento agroclimático para o pessegueiro e a nectarineira no Estado do Paraná. Revista Brasileira de Fruticultura, Jaboticabal, v.30, n.4, p.1040-1044, 2008.

CARVALHO, R.I.N.; ALVES, M.C.A. Intensidade de dormência das gemas de caquizeiro "Fuyu" no período do outono e inverno na região de Fazenda Rio Grande - PR. Pelotas, Revista Brasileira Agrociência, Pelotas, v.13, n.1, p.35-38, 2007.

CARVALHO, R.I.N.; BIASI, L.A. Índice para a avaliação da intensidade de dormência de gemas de fruteiras de clima temperado. Revista Brasileira de Fruticultura, Jaboticabal, v.34, n.3, p.936-940, 2012.

CARVALHO, R.I.N.; BIASI, L.A.; ZANETTE, F.; RENDOKE, J.C.; SANTOS, J.M.; PEREIRA, G.P. Dinâmica da dormência de gemas de caquizeiro 'Fuyu' em região de baixa ocorrência de frio. Scientia Agraria, Curitiba, v.11, p.57-63, 2010a.
CARVALHO, R.I.N.; BIASI, L.A.; ZANETTE, F.; RENDOKE, J.C.; SANTOS, J.M.; PEREIRA, G.P. Dormancy of 'Imperial Gala' apple and 'Hosui' pear tree buds in a region of low chill occurrence. Acta Scientiarum-Agronomy, Maringá, v.36, n.4, p.429-434, 2014.

CARVALHO, R.I.N.; RENDOKE, J.C.; BIASI, L.A.; ZANETTE, F. Metabolic activity evaluation of temperature tree fruit buds by using the tetrazolium test. Acta Horticulturae, The Hague, n.872, p.89$96,2010 \mathrm{~b}$

CARVALHO, R.I.N.; ZANETTE, F. Dinâmica da dormência de gemas de macieira 'Imperial Gala' durante o outono e inverno em região de baixa ocorrência de frio. Revista Brasileira de Fruticultura, Jaboticabal, v.26, n.1, p.65-68, 2004

DENNIS JR, F.G. Chilling requirements for the breaking of dormancy in buds of woody plants. HortScience, Alexandria, v.28, n.3, p.347-350, 2003.

EREZ,A. Bud dormancy: a suggestion for the control mechanism and its evolution. In: VIÉMONT, J.D.; CRABBÉ, J. Dormancy in plants: from whole plant behavior to cellular control. Cambridge: University Press, 2000. p.23-33.

HAWERROTH, F.J.; HERTER, F.G.; PETRI, J.L.; LEITE, G.B.; PEREIRA, J.F.M. Dormência em frutíferas de clima temperado. Pelotas: Embrapa Clima Temperado, 2010. 56 p. (Documentos, 310). Disponível em: $<\underline{\text { http://www.infoteca.cnptia. }}$ embrapa.br/bitstream/doc/884602/1/documento310. pdf $>$. Acesso em: 20 maio 2013.

LANG, G.A.; EARLY, J.D.; MARTIN, G.C.; DARNELL, R.L. Endo-, para- and ecodormancy: physiological terminology and classification for dormancy research. HortScience, Alexandria, v.22, n.3, p.371-178, 1987.

MARQUAT, C.; VANDAMME, M.; GENDRAUD, M.; PÉTEL, G. Dormancy in vegetative buds of peach: relation between carbohydrate absorption potentials and carbohydrate concentration in the bud during dormancy and its release. Scientia Horticulturae, Amsterdam, v.79, p.151-162, 1999. 
OLIVEIRA FILHO, P.R.C.; CARVALHO, R.I.N. Dinâmica da dormência em gemas de pessegueiro das variedades Eldorado e Ágata. Revista Acadêmica, Curitiba, v.1, n.3, p.41-46, 2003.

PETRI, J.L.; PALLADINI, L.A.; POLA, A.C. Dormência e indução a brotação em macieira. In: EPAGRI. A cultura da macieira. Florianópolis, 2006. p.261-297
R DEVELOPMENT CORE TEAM. R: a language and environment for statistical computing. Vienna: R Foundation for Statistical Computing, 2011. Disponível em: $<$ http://www.R-project.org $>$. Acesso em: 16 out. 2011. 